\title{
Wee1 kinase inhibitor MK-1775 induces apoptosis of acute lymphoblastic leukemia cells and enhances the efficacy of doxorubicin involving downregulation of Notch pathway
}

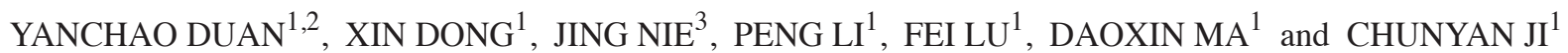 \\ ${ }^{1}$ Department of Hematology, Qilu Hospital, Shandong University, Jinan, Shandong 250012; \\ ${ }^{2}$ Department of Hematology, Affiliated Hospital of Taishan Medical University; \\ ${ }^{3}$ Department of Internal Medicine, The Central Hospital of Taian, Taian, Shandong 271000, P.R. China
}

Received February 4, 2017; Accepted January 18, 2018

DOI: $10.3892 / \mathrm{ol} .2018 .9291$

\begin{abstract}
Acute lymphoblastic leukemia (ALL) is an aggressive hematologic malignancy affecting pediatric and adult populations. Although the outcomes of ALL in children have improved markedly in previous years, limited treatment strategies are available at present for adult patients with ALL. Wee1 is a crucial cell cycle checkpoint kinase of $\mathrm{G} 2 / \mathrm{M}$ that regulates cell cycle progression and maintains chromatin integrity. MK-1775, a selective inhibitor of Wee1 has recently been identified to be able to induce apoptosis of tumor cells by abrogating G2/M checkpoint. The present study investigated the anti-leukemic activity of MK-1775 alone and in combination with doxorubicin (Adriamycin ${ }^{\circledR}$; ADM) in various human ALL cell lines. MK-1775 treatment induced apoptosis of ALL cells, accompanied by unscheduled mitotic entry and downregulation of Notch pathway. The anti-leukemic activity of MK-1775 was in a concentration- and time-dependent manner. The data also indicated that it decreased the half-maximal inhibitory concentration $\left(\mathrm{IC}_{50}\right)$ of ADM compared with the control group. The combination of MK-1775 and ADM induced an increased apoptotic rate compared with each agent alone. In addition, the human bone marrow stromal cell HS-5 cell line was detected to exhibit an increased $\mathrm{IC}_{50}$ value of MK-1775 treatment in contrast to ALL cell lines. It indicates that the hematopoietic supportive capability may remain intact during the treatment of MK-1775. Taken together, the Wee1 inhibitor MK-1775 may be an attractive agent in the treatment of patients with ALL.
\end{abstract}

Correspondence to: Professor Chunyan Ji, Department of Hematology, Qilu Hospital, Shandong University, 107 West Wenhua Road, Jinan, Shandong 250012, P.R. China

E-mail: jichunyan@sdu.edu.cn

Key words: Wee1, MK-1775, acute lymphoblastic leukemia, apoptosis, Notch

\section{Introduction}

Acute lymphoblastic leukemia (ALL) is one of the most common types of leukemia, which represents $75-80 \%$ of acute leukemia in children and $20 \%$ of all types of leukemia in adults (1-3). The cure rate and 5-year disease free survival (DFS) rate of children patients have markedly improved in previous years $(4,5)$. However, the outcomes of adult patients remain poor (6). The 5-year overall survival (OS) rate of adults of young age (15-39 years old) was demonstrated to be between 42 and $63 \%$. It decreased to $24.1 \%$ in those patients between 40 and 59 years old, and to $17.7 \%$ in patients between the ages of 60 and 69 (7). Resistance to chemical drugs is one of the primary factors that leads to treatment failure (8). Therefore, novel agents with high efficacy rates are required to treat this threating malignancy.

Wee1 encodes a nuclear protein measuring $96 \mathrm{KD}$, which is a tyrosine kinase belonging to the Ser/Thr family of protein kinases (9). It is markedly active during $\mathrm{S}$ and G2 phase of the cell cycle, and acts as a crucial regulator of the G2/M and DNA damage checkpoints (9). Cyclin-dependent kinase 1 (CDK1) and cyclin B comprise the maturation promoting factor, which initiates the process of mitosis $(10,11)$. Weel phosphorylates the amino acids Tyr15 and Thr14 of CDK1, thus inactivating the CDK1-cyclinB complex, arresting cell cycle and preventing mitotic entry $(10,11)$. MK-1775 is a selective Weel tyrosine kinase inhibitor that inhibits the activity of Wee1 in an adenosine 5'-triphosphate-competitive manner (12). It induces cell apoptosis by abrogating the G2/M checkpoint in a variety of solid tumors, including: Neuroblastoma (13); Ewing sarcoma (14); glioblastoma (15); pancreatic (16), prostate (17) and breast cancer (18); hepatic carcinoma (19); and acute myeloid leukemia $(20,21)$. However, the role of Weel in ALL and the potential anti-ALL activity of MK-1775 have not been well elucidated. The present study evaluated the anti-ALL activity of MK-1775 as a single agent and in combination with the cytotoxic drug doxorubicin (Adriamycin ${ }^{\circledR}$; ADM). Potential involvement of the Notch and $\mathrm{RAC}$-alpha serine/threonine-protein kinase (Akt)/mechanistic target of rapamycin (mTOR) signaling pathway during the treatment was also investigated. The results provided the 
preliminary evidence for the clinical application of MK-1775 in the treatment of patients with ALL.

\section{Materials and methods}

Cell lines, culture mediums and reagents. Human ALL cells Nalm-6 [B-cell-ALL (B-ALL)], Molt-4 [T-cell-ALL (T-ALL)], Jurkat (T-ALL), Sup-T1 (T-ALL) and the human bone marrow stromal cell HS-5 cell line were purchased from The Cell Bank of Type Culture Collection of Chinese Academy of Medical Science (Shanghai, China) and cultured in RPMI-1640 (Gibco; Thermo Fisher Scientific, Inc., Waltham, MA, USA) supplemented with $10 \%$ fetal bovine serum (Gibco; Thermo Fisher Scientific, Inc.) and $1 \%$ penicillin-streptomycin (Solarbio Life Sciences, Beijing, China ) in a $37^{\circ} \mathrm{C}$ humidified incubator containing $5 \% \mathrm{CO}_{2}$ and $95 \%$ air. The Weel inhibitor, MK-1775 (Selleck Chemicals, Houston, TX), was dissolved in concentrations of dimethyl sulfoxide (DMSO) ranging from $0,50,100,300,500$ to $1,000 \mathrm{nM}$ and stored at $-80^{\circ} \mathrm{C}$. ADM (Sigma-Aldrich; Merck KGaA, Darmstadt, Germany) was dissolved in $0.9 \%$ saline and stored at $4{ }^{\circ} \mathrm{C}$.

Cell culture and viability assays. Cells were seeded at a density of 5,000 cells/well in 96 -well plates and incubated at $37^{\circ} \mathrm{C}$ with MK-1775 (0, 50, 100,300, 500 and 1,000 nM), $\operatorname{ADM}(0,0.1,0.2$, $0.3,0.4$ and $0.5 \mathrm{mg} / \mathrm{ml}$ ) or a combination of two drugs for indicated time intervals $(0,24,48$ and $72 \mathrm{~h})$. Then, $10 \mu \mathrm{l}$ MTT was added to each well. Following an additional $4 \mathrm{~h}$ of incubation at $37^{\circ} \mathrm{C}$, the supernatant was removed following centrifugation at $300 \mathrm{x} \mathrm{g}$ and $25^{\circ} \mathrm{C}$ for $10 \mathrm{~min}$, and $100 \mu \mathrm{l}$ DMSO was added to each well. Then, the optical density was measured at $570 \mathrm{~nm}$ on a spectrophotometer (Bio-Rad Laboratories, Inc., Hercules, CA, USA). The half-maximal inhibitory concentration $\left(\mathrm{IC}_{50}\right)$ was defined as the drug concentration required to reduce cellular viability to $50 \%$ of the control well (without treatment). The $\mathrm{IC}_{50}$ was calculated according to the following formulas: $\mathrm{Y}_{1}-\mathrm{Y}_{2} / \mathrm{X}_{1}-\mathrm{X}_{2}=\mathrm{M}$; $\mathrm{Y}_{1}-\mathrm{MX}_{1}=\mathrm{B}$; B-50/-M=IC $\mathrm{C}_{50}$, where $\left(\mathrm{X}_{1}, \mathrm{Y}_{1}\right)$ and $\left(\mathrm{X}_{2}, \mathrm{Y}_{2}\right)$ are two points below and above $50 \%$ inhibition rate, and where $\mathrm{X}$ denotes drug concentration and $\mathrm{Y}$ represents the \% inhibition rate.

Apoptosis assay. Cells were collected by centrifugation at $300 \mathrm{x} \mathrm{g}$ and $4^{\circ} \mathrm{C}$ for $5 \mathrm{~min}$ and washed twice with cold PBS, then suspended in $400 \mu 1$ 10-fold diluted Annexin V connection solution (cat. no., BB-4101-2, Best Bio, China) and incubated with $5 \mu \mathrm{l}$ Annexin V-fluorescein isothiocyanate (FITC) (cat. no., BB-4101-2, Best bio) solution at $4^{\circ} \mathrm{C}$ in dark for $15 \mathrm{~min}$. A total of $10 \mu \mathrm{l}$ propidium iodide (PI; (cat. no., BB-4101-2 Best bio) solution was added and cells were incubated at $25^{\circ} \mathrm{C}$ in the dark for $5 \mathrm{~min}$. Following staining, cells were analyzed immediately with flow cytometry (FCM). Annexin V-positive cells were considered as apoptotic. The data was analyzed with Summit 5.2 software (Beckman Coulter, Inc.).

Cell cycle analysis. Cultured cells were collected by centrifugation $300 \mathrm{x} \mathrm{g}$ at $4^{\circ} \mathrm{C}$ for $10 \mathrm{~min}$, washed twice with cold PBS and fixed with $75 \%$ ice-cold ethyl alcohol for $1 \mathrm{~h}$. Then, cells were collected by centrifugation with $300 \mathrm{xg}$ at $4^{\circ} \mathrm{C}$ for $10 \mathrm{~min}$ and re-suspended in $200 \mu \mathrm{l}$ cold PBS. A total of $400 \mu \mathrm{l}$ PI solution was added to the tube and incubated at $4^{\circ} \mathrm{C}$ in dark for 30 min. The DNA index (22) was measured using FCM. Cell cycle distribution was calculated according to the DNA index with ModFit LT 3.1 software (Verity software House, Inc., Topsham, ME, USA).

Protein extraction and western blot analysis. Cells were collected and lysed in lysis buffer (50 mmol/1 Tris (pH7.5), $100 \mathrm{mmol} / 1 \mathrm{NaCl}, 1 \mathrm{mmol} / \mathrm{l}$ EDTA, 0.5\% NP40, 0.5\% Triton $\mathrm{X}-100,2.5 \mathrm{mmol} / \mathrm{l}$ sodium orthovanadate, $10 \mu \mathrm{l} / \mathrm{ml}$ protease inhibitor cocktail, $1 \mathrm{mmol} / \mathrm{l}$ phenylmethylsulfonyl fluoride) for $20 \mathrm{~min}$ at $4^{\circ} \mathrm{C}$. The total protein was obtained by centrifugation at $20,000 \mathrm{x} \mathrm{g}$ at $4^{\circ} \mathrm{C}$ for $15 \mathrm{~min}$. Protein concentrations were determined with the BCA Protein Assay reagent (Pierce; Thermo Fisher Scientific, Inc.) according to the manufacturer's protocol. Protein ( $20 \mu \mathrm{g} / \mathrm{lane})$ was separated by $5 \%$ SDS-PAGE, and transferred onto the nitrocellulose membrane. Membranes were blocked with blocking buffer $[0.1 \mathrm{~mol} / 1$ Tris $(\mathrm{pH} 7.5)$, $0.9 \% \mathrm{NaCl}$ and $0.05 \%$ Tween-20 (TBST) containing 5\% non-fat milk powder] for $1 \mathrm{~h}$ at $25^{\circ} \mathrm{C}$, then incubated at $4^{\circ} \mathrm{C}$ overnight with primary antibodies p-CDK1 (Tyr15; cat. no., ab47594; Abcam, Cambridge, UK), total CDK1 (cat. no., A17; Abcam), Notch1-intracellular domain (ICN; cat. no., ab8925; Abcam), Notch3-ICN (cat.no.,ab23426; Abcam),HES1 (cat.no.,ab108937; Abcam), $\beta$-actin (cat. no., 4967; Cell Signaling Technology, Inc., Beverly, MA, USA), $\gamma$-H2AX (p-H2AX Ser139) ( cat. no., 9718, Cell Signaling Technology, Inc.), phospho-Histone H3 (Ser10) (cat. no., 53348; Cell Signaling Technology, Inc.), Akt (cat. no., 2920; Cell Signaling Technology, Inc.), p-AKT (Ser473; cat. no., 4060, Cell Signaling Technology, Inc.), mTOR (cat. no., 2983; Cell Signaling Technology, Inc,), phosphorylated-mTOR (Ser-2448; cat. no., 2971; Cell Signaling Technology, Inc.), poly (ADP-ribose) polymerase 1 PARP1 (cat. no., SC-8007; Santa Cruz Biotechnology, Inc., Hercules, CA, USA), all at 1:1,000 dilution. Followed by incubation with anti-rabbit (cat. no., ZB-2301; Beijing Zhongshan Golden Bridge Biotechnology Co., Ltd. Beijing, China) or mouse (cat. no., ZK-9600; Beijing Zhongshan Golden Bridge Biotechnology Co., Ltd. Beijing, China) horseradish peroxidase (HRP)-conjugated antibodies at 1:5,000 dilution at $4^{\circ} \mathrm{C}$ for $1 \mathrm{~h}$ and reaction with chemiluminescent HRP substrate (EMD Millipore, Billerica, MA, USA), probed proteins were detected on a chemiluminescent autography machine Fluor Chem E (ProteinSimple, San Jose, CA, USA). Software ImageJ 1.44p (National Institute of Health, Bethseda, MD, USA) was used to perform densitometric analysis.

Statistical analysis. Measurement data are presented as mean \pm standard deviation. Differences among $\geq$ three groups were determined by one-way analysis of variance, followed by Student-Newman-Keuls post-hoc test for multiple comparisons, whereas differences between two groups were evaluated by a Student's t-test. $\mathrm{P}<0.05$ was considered to indicate a statistically significant difference. Statistical analysis was performed using the SPSS 17.0 statistical software (SPSS, Inc., Chicago, IL, USA).

\section{Results}

MK-1775 inhibits the viability of ALL cells. To determine the effect of MK-1775 on cell viability, human ALL Nalm-6, Molt-4, Jurkat and Sup-T1 cell lines and human bone marrow 
A

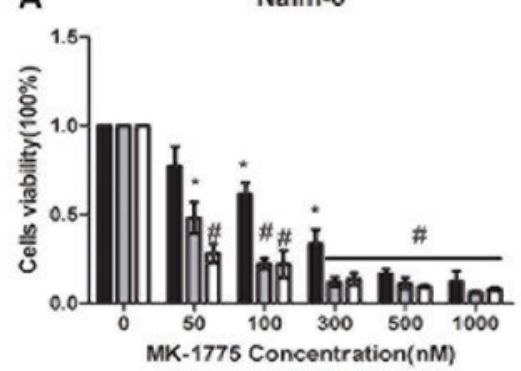

Sup-T1

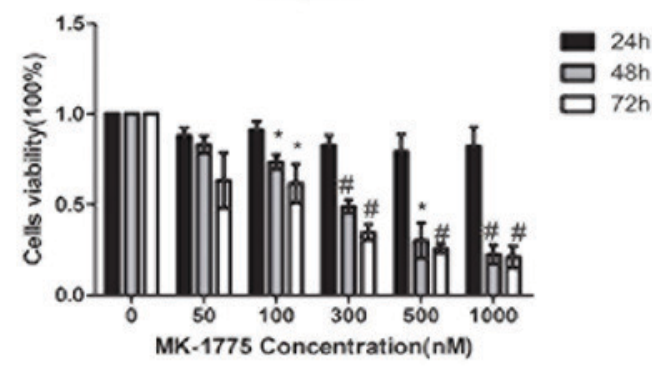

HS-5

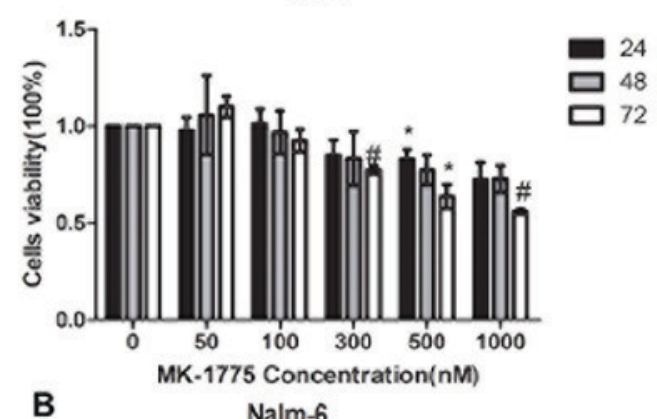

B

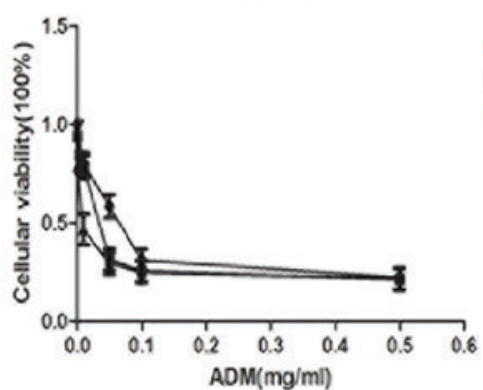

Jurkat

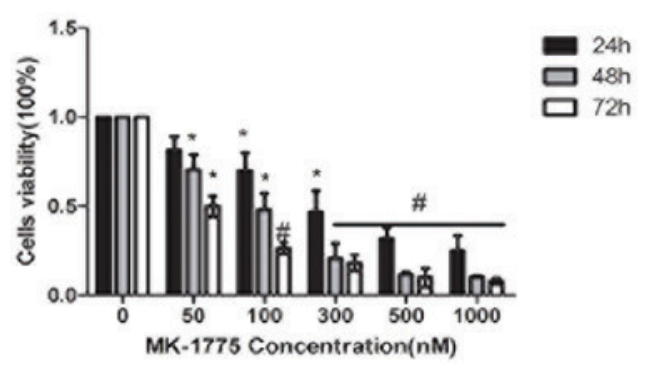

Molt-4

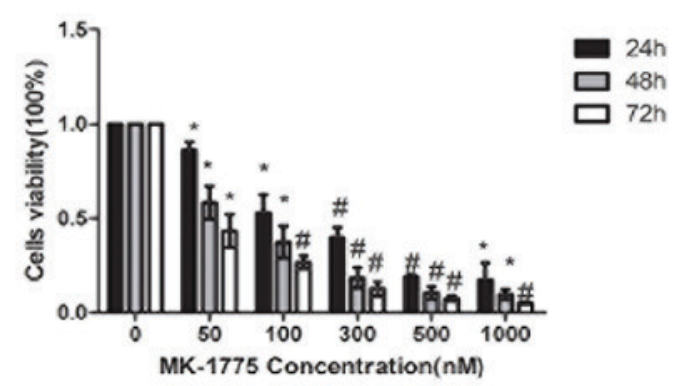

Jurkat

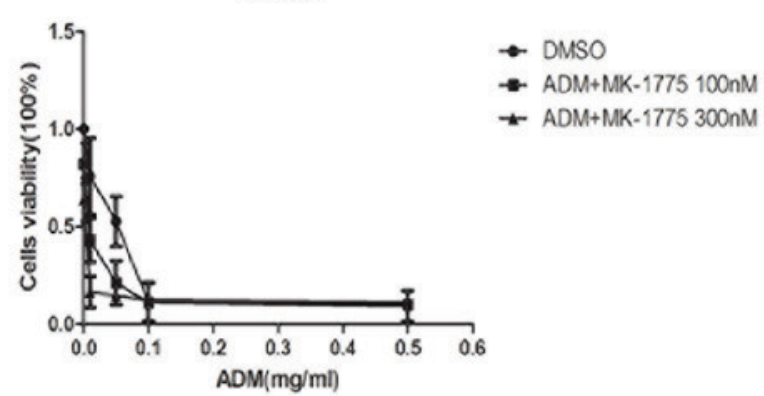

Figure 1. Effects of MK-1775 on the viability of ALL cells and human bone marrow stromal cell. (A) ALL Nalm-6, Jurkat, Molt-4, Sup-T1 and bone marrow stromal cell HS-5 cell lines were treated with 0,50, 100, 300, 500 and 1,000 nM of MK-1775 for 24, 48 and $72 \mathrm{~h}$. MTT was used to detect cell viability. Data is presented as the percentages of the corresponding untreated control, and as mean $\pm \mathrm{SD}$. ${ }^{\text {}} \mathrm{P}<0.05$ and ${ }^{\text {" }} \mathrm{P}<0.01$ compared with the control $(0 \mathrm{nM})$. The results are representative of 3 independent experiments. (B) Nalm- 6 and Jurkat were treated with ADM and different concentrations of MK-1775 for 48 h. The half-maximal inhibitory concentration of ADM was evaluated. Values are presented as mean \pm SD. Results are representative of 3 independent experiments. $\mathrm{SD}$, standard deviation; ADM, doxorubicin.

stromal cell HS-5 cell line were treated with MK-1775 in increasing concentrations for 24,48 and $72 \mathrm{~h}$, and cell viability was detected by MTT assay. As demonstrated in Fig. 1A, cell viability was suppressed in a concentration- and time-dependent manner. The $\mathrm{IC}_{50}$ values of the ALL cells were in a range of $45.9 \pm 3.9$ to $347.4 \pm 95 \mathrm{nmol} / \mathrm{l}$ at $48 \mathrm{~h}$, and the $\mathrm{IC}_{50}$ of the HS-50 cell line was $1472.0 \pm 304.8 \mathrm{nmol} / 1$, which was increased compared with each ALL cell $(\mathrm{P}<0.05$; Table I). Then, the effects of MK-1775 on the anti-leukemia effect of ADM on the ALL cells was detected. Nalm-6 (B-ALL) and Jurkat (T-ALL) cells were treated with increased doses of
ADM with or without MK-1775 for $48 \mathrm{~h}$. The data indicated that the $\mathrm{IC}_{50}$ of $\mathrm{ADM}$ was decreased with the additional application of MK-1775 compared with single ADM treatment (Fig. 1B).

MK-1775 promotes cells into G2/M phase. To determine the effect of MK-1775 on the cell cycle progression of ALL cells in vitro, Nalm-6 and Jurkat cells were cultured in 6-well plates with 0,100 or $300 \mathrm{nM}$ MK-1775 for $24 \mathrm{~h}$. Cells were collected and stained with PI. Cell cycle analysis was performed with an FCM assay. As indicated in Fig. 2, compared with the control 
Table I. $\mathrm{IC}_{50}$ of MK-1775 against ALL cell lines.

\begin{tabular}{lclr}
\hline Cell line & Cell type & p53 & \multicolumn{1}{c}{ IC $_{50}, \mathrm{nM}$} \\
\hline Nalm-6 & B-ALL & WT & $45.9 \pm 3.9^{\mathrm{a}}$ \\
Sup-T1 & T-ALL & MUT & $347.4 \pm 95.0^{\mathrm{a}}$ \\
Jurkat & T-ALL & MUT & $137.4 \pm 33.9^{\mathrm{a}}$ \\
Molt-4 & T-ALL & MUT & $67.6 \pm 31.8^{\mathrm{a}}$ \\
HS-5 & BMSC & WT & $1,472.0 \pm 304.8$ \\
\hline
\end{tabular}

ALL, acute lymphoblastic leukemia; B-ALL, B-cell acute lymphoblastic leukemia; T-ALL, T-cell acute lymphoblastic leukemia; WT, wild type; MUT, mutation. MUT, mutated; WT, wild type; $\%$, tumor protein $53 ; \mathrm{IC}_{50}$, half-maximal inhibitory concentration. ${ }^{\mathrm{a}} \mathrm{P}<0.05$ compared with HS- 5 cell line.

group, treatment with $300 \mathrm{nM}$ MK-1775 decreased the proportion of Jurkat cells in G1 phase, and more cells were arrested at $\mathrm{G} 2 / \mathrm{M}$ phase $(\mathrm{P}<0.05)$. The proportion of each phase of Nalm-6 cells treated with 100 or 300 nM MK-1775 did not change significantly compared with the control group $(\mathrm{P}>0.05)$.

MK-1775 induces apoptosis of ALL cells. To determine the effect of MK-1775 induced apoptosis in ALL cells, Nalm-6 and Jurkat were cultured with MK-1775 (0, 100 or $300 \mathrm{nM})$ for $48 \mathrm{~h}$, then Annexin V-FITC/PI dual staining followed by flow cytometric analysis was performed. The proportion of apoptotic Nalm-6 cells was $3.46 \pm 2.25,64.82 \pm 18.44$ and $88.83 \pm 7.65 \%$ respectively, and the proportion of apoptotic Jurkat cells was $2.12 \pm 0.47,41.26 \pm 12.30$ and $70.08 \pm 8.52 \%$, respectively (Fig. 3).

Then, the synergistic effect of MK-1775 and ADM was detected. Nalm-6 and Jurkat cells were treated with control, $0.05 \mathrm{mg} / \mathrm{ml}$ ADM, MK-1775 $100 \mathrm{nM}$, or the combination for $24 \mathrm{~h}$, and apoptosis analysis was performed with flow cytometry. The apoptotic rate of the Nalm- 6 cells in the control, ADM, MK-1775 and combination groups was $2.30 \pm 1.13,12.8 \pm 5.07$, $17.15 \pm 7.89$ and $49.42 \pm 6.82 \%$ respectively; the apoptotic rate of the Jurkat cells was 3.01 $\pm 1.31,18.50 \pm 7.67,23.25 \pm 10.87$ and $67.16 \pm 7.67 \%$, respectively. MK-1775 combined with ADM induced higher apoptotic rates compared with each single agent and the control in the Nalm-6 and Jurkat cell lines ( $\mathrm{P}<0.05$; Fig. 3).

MK-1775 induces apoptosis due to unscheduled mitotic entry and downregulation of Notch pathway. To determine the underlying molecular mechanism of the apoptosis induced by MK-1775, Nalm-6 and Jurkat cells were treated with $0.05 \mathrm{mg} / \mathrm{ml}$ ADM, $300 \mathrm{nM}$ MK-1775, or the combination for $24 \mathrm{~h}$, then western blotting was performed to detect the expression of the associated proteins. As demonstrated in Fig. 4, MK-1775 and ADM increased the expression of H2A histone family, member $X(\gamma-\mathrm{H} 2 \mathrm{AX})$ and promoted the cleavage of PARP1, which indicated breakage of DNA strand and apoptosis of ALL cells. Additional analysis revealed that MK-1775 treatment suppressed the phosphorylation of CDK1 at Tyr15 and increased the expression of p-H3 (Ser10), which is an index of mitotic entry (23). It indicated that apoptosis of ALL cells induced by MK-1775 was due to abrogation of G2/M checkpoint and unscheduled mitosis entry. Different from MK-1775, ADM treatment increased the phosphorylation of CDK1 and decreased the expression of $\mathrm{p}-\mathrm{H} 3$, which indicated that mitotic entry in the cells was inhibited. In addition, the data indicated that the combination of ADM and MK-1775 induced increased $\gamma$-H2AX levels and more cleaved PARP1 compared with treatment with ADM alone $(\mathrm{P}<0.05)$, which suggests that MK-1775 may enhance the efficacy of ADM in the treatment of ALL. Next, the potential signaling pathway involved in the apoptosis induced by MK-1775 treatment was detected. The results indicated that Notch1 ICN and Notch3 ICN levels were downregulated by MK-1775 $(\mathrm{P}<0.05)$, but that the mTOR pathway was not changed ( $\mathrm{P}>0.05$; Fig. 4). However, ADM treatment did not affect the Notch or mTOR pathways as significantly $(\mathrm{P}>0.05)$. The relative protein expression was calculated as the density ratio of the protein to be detected to actin.

\section{Discussion}

The DNA repairing pathway serves a critical role in the survival of cancer cells (24). The majority of traditional anti-leukemia chemicals are DNA damaging agents, including antimetabolites, alkylating agents and topoisomerase inhibitors (25). Tumor protein 53 (p53) serves as a key regulator of G1/S checkpoint (26). It blocks the initiation of S-phase and activates DNA repairing proteins when DNA has sustained damage (27). However, p53 was mutated in a variety of types of cancer; consequently, there is dysfunction in the G1/S checkpoint and cells with DNA lesions can enter S phase without DNA repair. In these cancer cells, DNA repair relies on the G2/M rather than the G1/S checkpoint (28).

Wee1 is a crucial cell cycle checkpoint kinase of G2/M that regulates cell cycle progression and maintains chromatin integrity (29). In addition, Weel serves a critical role in regulating histone synthesis and spindle formation (30). It phosphorylates the amino acids Tyr37 of $\mathrm{H}_{2} \mathrm{~B}$ to terminate the synthesis of histone to maintain the proper histone/DNA stoichiometry before mitotic entry. Weel inhibition may force cells in S phase directly into mitosis without completing DNA synthesis, resulting in highly abnormal mitoses characterized by dispersed chromosomes and disorganized bipolar spindles, ultimately resulting in mitotic exit with gross micronuclei formation and apoptosis (31-33). MK-1775 is a selective Weel kinase inhibitor that has demonstrated a high rate of anti-tumor activity in a variety of types of cancer.

The data of the present study indicated that the B-ALL and T-ALL cell lines were sensitive to the treatment of Weel inhibitor MK-1775 in vitro. It inhibited cell viability and induced apoptosis in a concentration- and time-dependent manner. MK-1775 treatment suppressed the phosphorylation of CDK1 and increased the expression levels of $\mathrm{p}-\mathrm{H} 3$, which is an indicator of mitotic entry (23). Increased expression levels of $\gamma-\mathrm{H} 2 \mathrm{AX}$ suggested that the unscheduled mitotic entry induced by MK-1775 led to more extensive DNA lesions. PARP is a crucial enzyme responsible for the repair of single-strand DNA breaks (34). It is cleaved by caspase during the process of apoptosis, and consequently becomes inactive (35). The data of the present study indicated that MK-1775 treatment led to DNA repair suppression and apoptosis of ALL cells, characterized 
Nalm-6
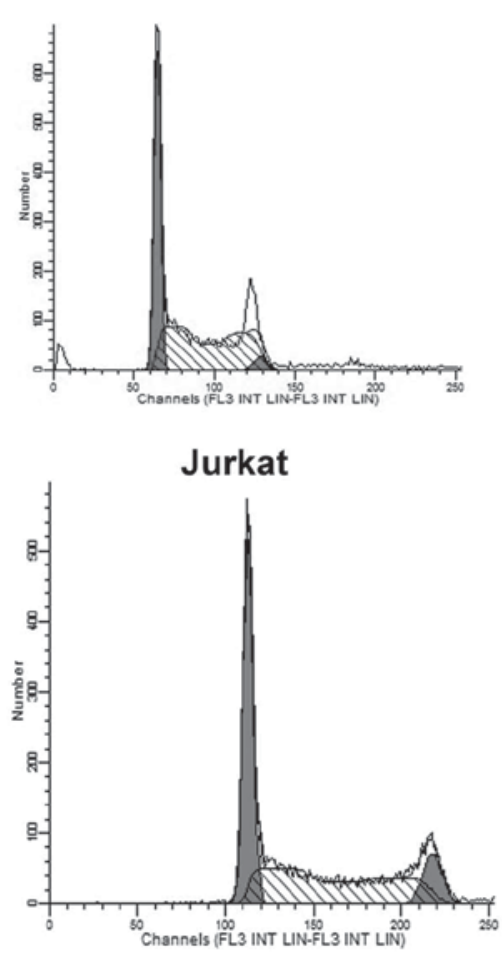

Control
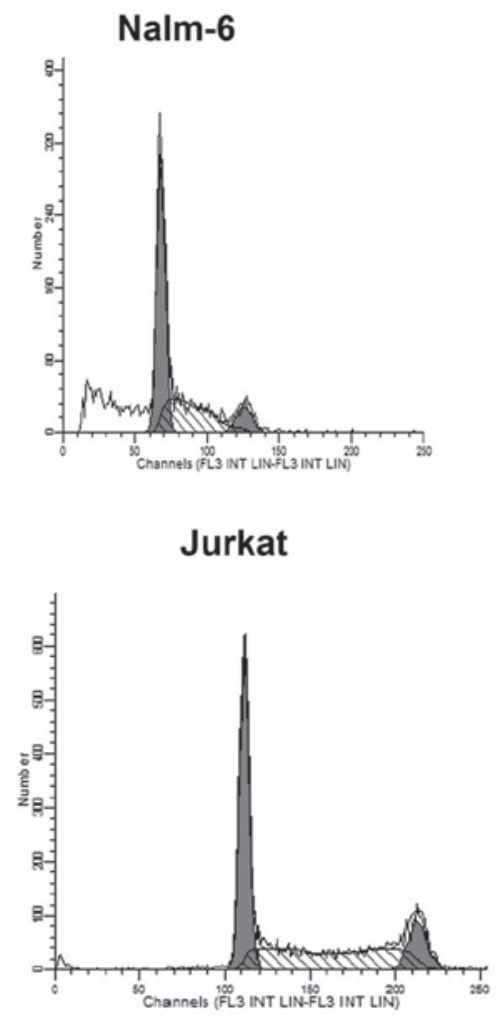

MK-1775 100 nM
Nalm-6

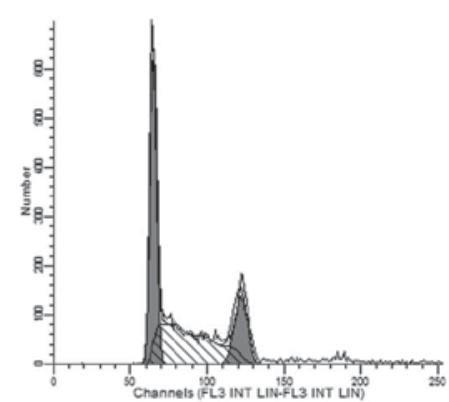

Jurkat

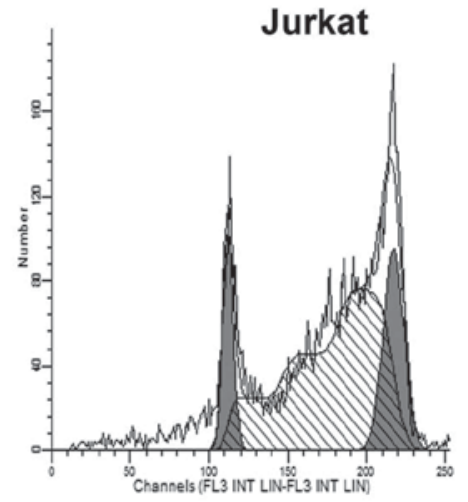

MK-1775 300 nM
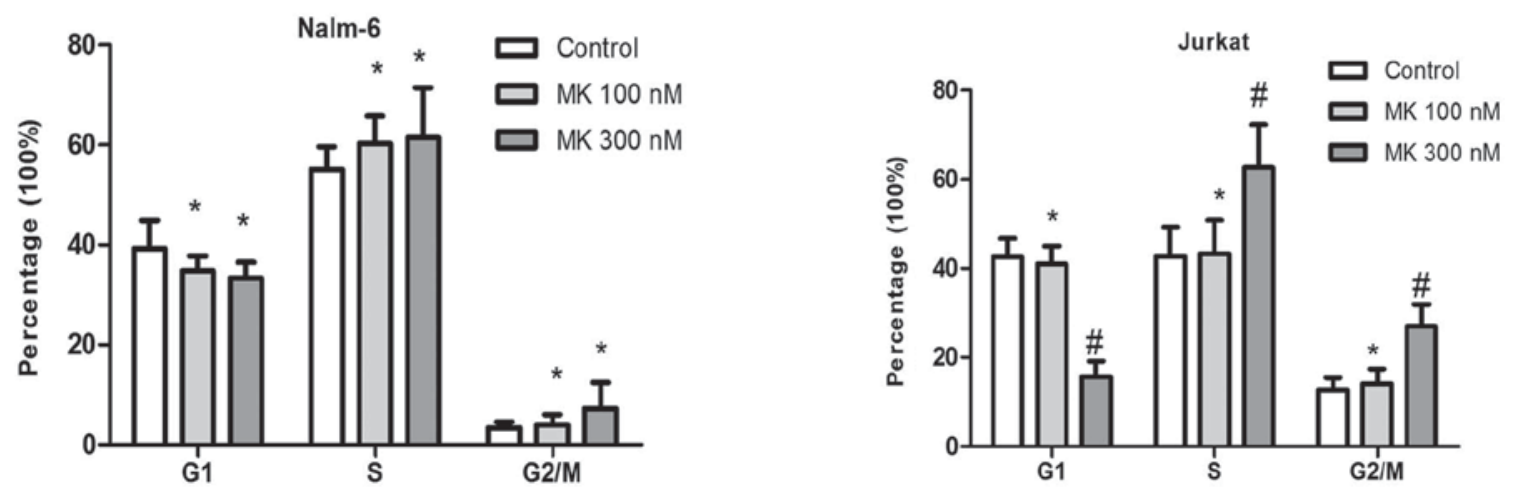

Figure 2. Effect of MK-1775 on the cell cycle progression of acute lymphoblastic leukemia cells. Nalm-6 and Jurkat were treated with 0, 100 and 300 nM of MK-1775 for $24 \mathrm{~h}$. Flow cytometry was used to detect the cell cycle distribution. Values are presented as mean \pm standard deviation. Results are representative of 3 independent experiments. ${ }^{*} \mathrm{P}>0.05$ and ${ }^{\#} \mathrm{P}<0.05$ compared with control.

by cleavage of PARP1. ADM is a common agent applied in the treatment of ALL that destroys DNA structure and inhibits the replication of DNA (36). The results of the present study indicated that the combination of ADM and MK-1775 led to increased levels of DNA damage compared with each single agent, and as a result induced and increased level of apoptosis. MK-1775 treatment decreased the $\mathrm{IC}_{50}$ of ADM in the Jurkat and Nalm- 6 cells, indicating that it may increase the sensitivity of ALL cells to ADM treatment. In addition, the present study demonstrated that the $\mathrm{IC}_{50}$ of MK-1775 in the HS-5 cell line was increased compared with all ALL cell types. It indicates that the hematopoietic supportive capacity of bone marrow stromal cells may be reserved during the treatment of MK-1775. It also agrees with the conclusion that MK-1775 is a well-tolerated agent with high safety (37). In addition, it was identified that MK-1775 exhibited an anti-ALL effect not only in cells with p53 mutations (Jurkat, Sup-T1 and Molt-4), but also in cells with wild type p53 (Nalm-6). A similar result was also identified in sarcomas (38), which indicates that the status of p53 is not the only predicator of response to the Weel inhibitor MK-1775. Other studies revealed that the level of Wee1 expression and CDK1 phosphorylation are also responsible for the efficiency of Weel inhibitor in untreated glioblastoma and osteosarcoma $(39,40)$.

The present study additionally investigated the potential effect of MK-1775 on the Notch pathway, which serves a critical role in the survival of ALL cells (41). Notch is a conserved transmembrane pathway that consists of 5 ligands [Jagged1, Jagged2, Delta-like ligand (DLL)-1, DLL3, and DLL4] and four receptors (Notch1-4) in mammals (42). When bound with 
A

$\bar{a}$
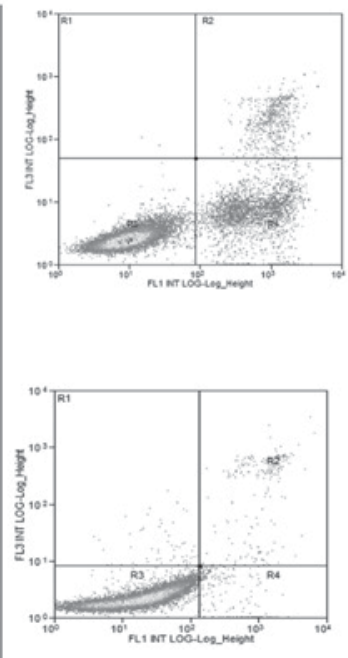

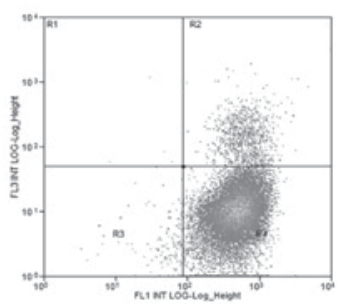

Nalm-6

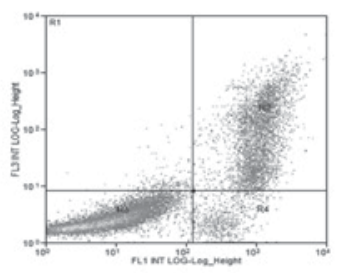

Jurkat
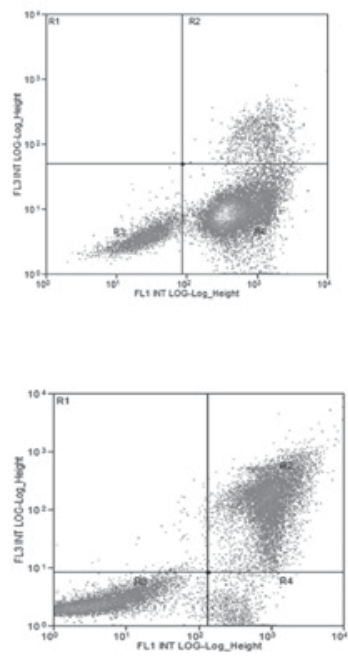

Annexin V-FITC
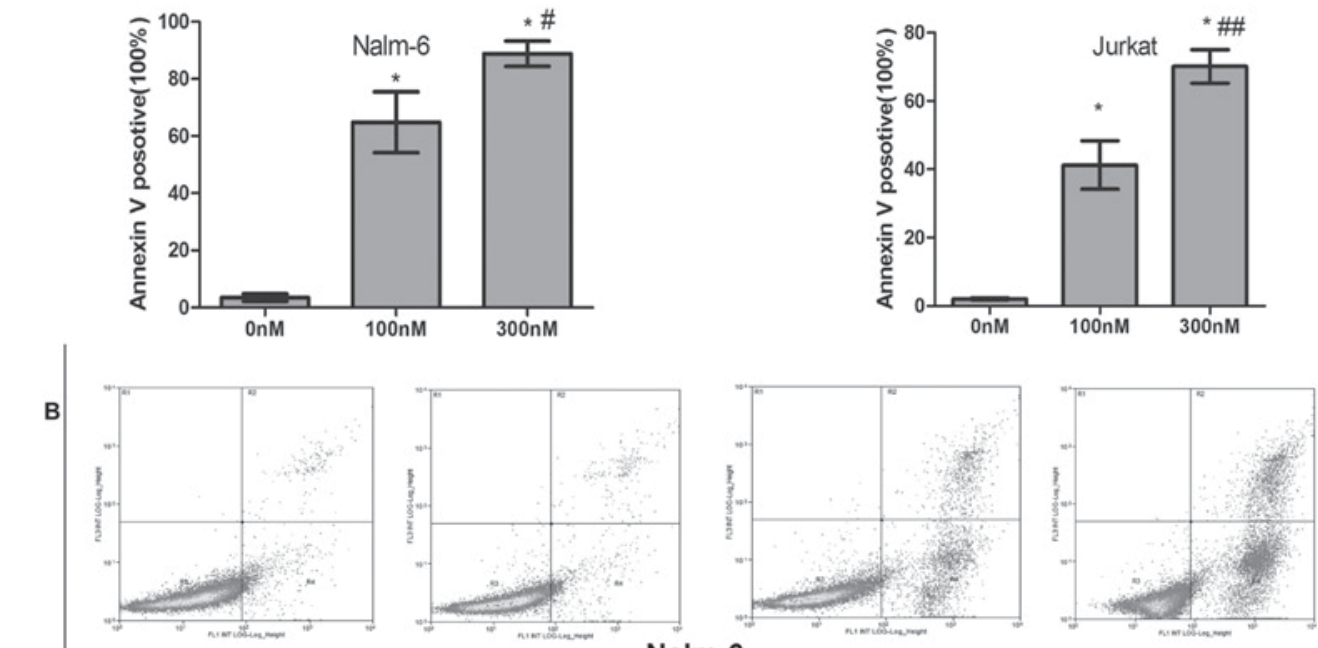

$\overline{\mathbf{n}}$
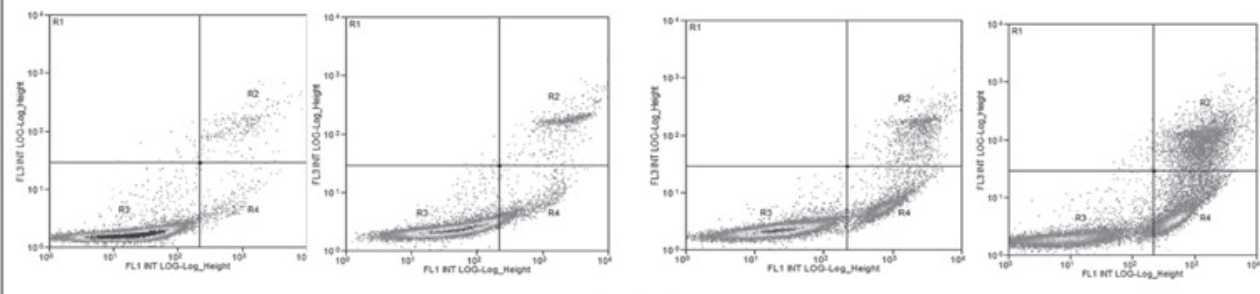

Jurkat

\section{Annexin V-FITC}
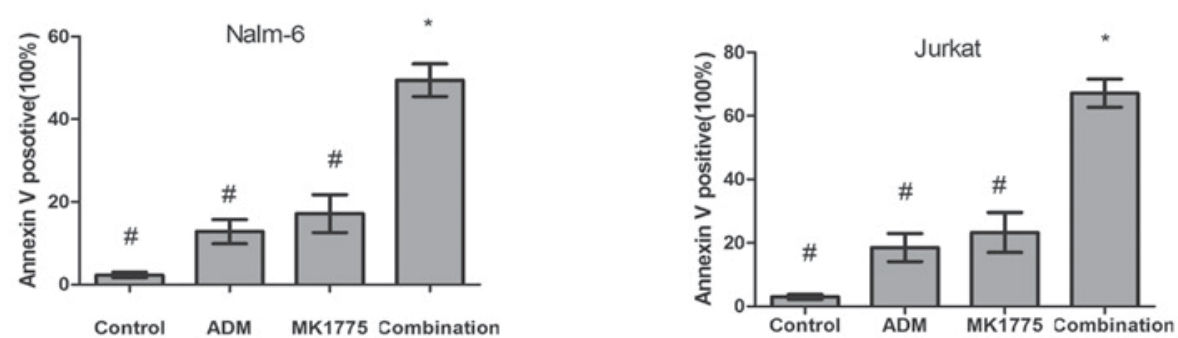

Figure 3. Effect of MK-1775 on the apoptosis of acute lymphoblastic leukemia cells. (A) Nalm-6 and Jurkat were treated with 0, 100 and 300 nM MK-1775 for $48 \mathrm{~h}$. Flow cytometry was used to detect the apoptotic cells. Annexin V-FITC-positive cells were considered as apoptotic. Values are presented as mean \pm standard deviation. Results are representative of 3 independent experiments. " $\mathrm{P}<0.05$ compared with $0 \mathrm{nM},{ }^{*} \mathrm{P}>0.05$ compared with $100 \mathrm{nM}$ group, ${ }^{\# \#} \mathrm{P}<0.05$ compared with $100 \mathrm{nM}$ group. (B) Nalm- 6 and Jurkat cells were treated with control, $100 \mathrm{nM} \mathrm{MK}-1775,0.05 \mathrm{mg} / \mathrm{ml}$ ADM or the combination for $24 \mathrm{~h}$. Flow cytometry was used to detect apoptotic cells. Values are presented as mean \pm standard deviation. Results are representative of 3 independent experiments. MK-1775 combined with doxorubicin induced higher apoptotic rates compared with each single agent and the control in the Nalm-6 and Jurkat cell lines $\left(\right.$ ( $\mathrm{P}<0.05$ compared with $\left.{ }^{\#}\right)$. FITC, fluorescein isothiocyanate; PI propidium iodide; ADM, doxorubicin. 

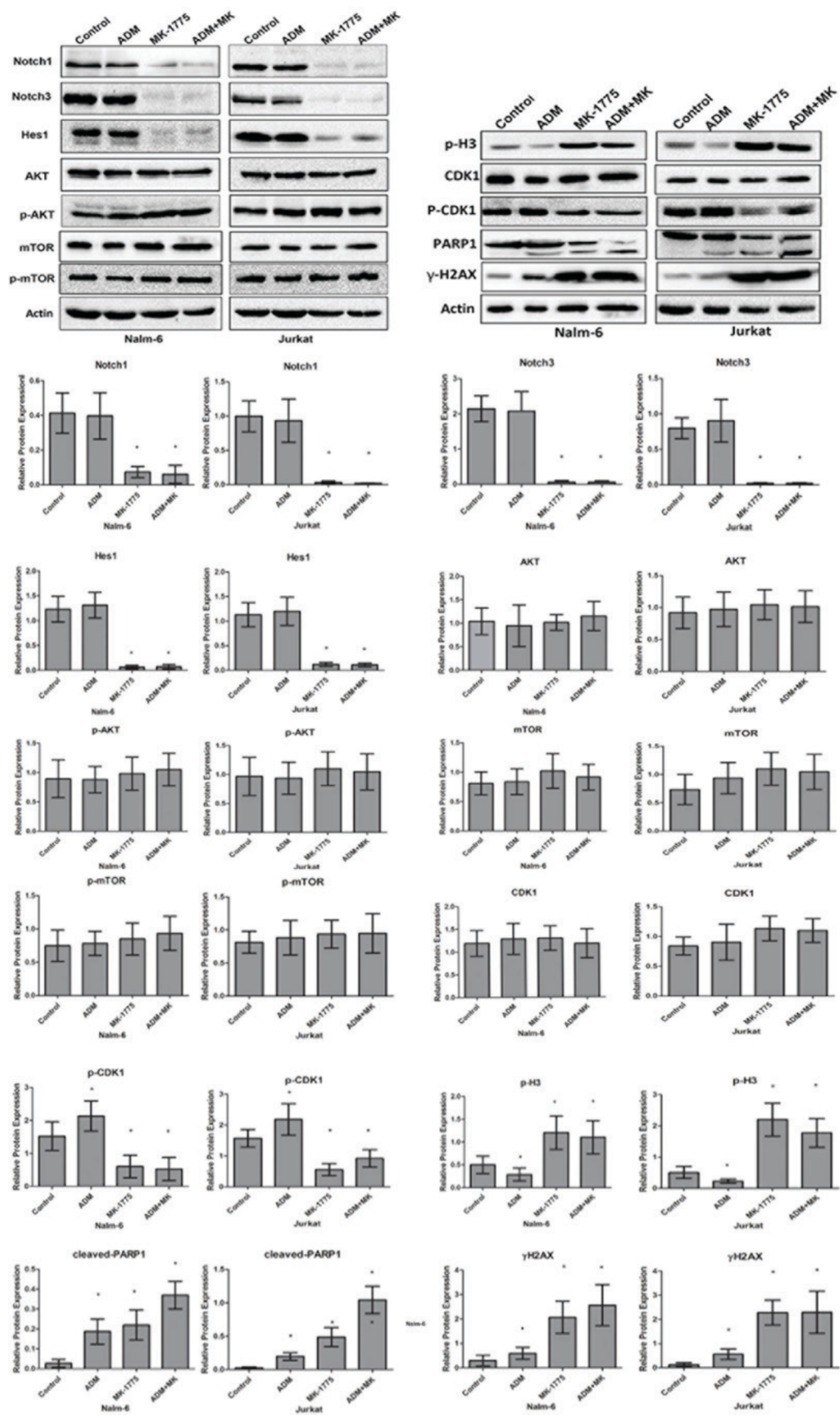

Figure 4. MK-1775 induced apoptosis due to unscheduled mitotic entry and downregulation of Notch pathway. MK-1775 inhibited the phosphorylation of CDK1, induced apoptosis characterized by cleavage of PARP-1 and increase of $\gamma$-H2AX expression. Notch1 ICN and Notch3 ICN were downregulated, but mTOR levels were not altered by MK- 1775 treatment. Results are representative of 3 independent experiments. $\beta$-actin protein served as a protein loading control. "P<0.05 vs. control. ADM, doxorubicin; CDK1, cyclin-dependent kinase 1; mTOR, mechanistic target of rapamycin; ICN, intracellular domain; p, phosphorylated; Hes1, hairy and enhancer of split-1; Akt, RAC-alpha serine/threonine protein kinase; p-H3, phosphorylated histone H3; PARP1, poly (ADP-ribose) polymerase 1; rH2AX, H2A histone family, member X. 
its corresponding ligands, the Notch ICN is released from the membrane, then translocated into the nucleus and associates with transcription factor Recombination signal binding protein for immunoglobulin Kappa $\mathbf{J}$ region, leading to the expression of Notch target genes, for example the HES1/Hes related family BHLH transcription factor with YRPW motif 1 family. A previous study indicated that $>50 \%$ of T-ALL cases contain activating mutations in the Notch1 gene (43). Aberrant activation of Notch1 maintains T-ALL cells survival and promotes extra-medullary infiltration $(44,45)$. and downregulation of Notch-1 may increase the sensitivity to chemotherapy of co-cultured human T-ALL Jurkat cells (46). In B-ALL, Notch-3 and Notch-4 signaling may rescue leukemia cells in contact with human bone marrow-derived mesenchymal stromal cells from apoptosis (47). In addition, Notch has been demonstrated to interact with other signaling pathways in the survival of tumor cells $(48,49)$. It may positively regulate the activity of mTOR pathway in T-ALL (50). Downregulation of Notch-1 may inhibit prostate cancer cell growth and induce apoptosis via inactivation of $\mathrm{Akt} / \mathrm{mTOR}$ and NF- $\mathrm{\kappa B}$ signaling pathways (51). In the present study, Notch1 and Notch3 were detected to be downregulated by MK-1775 treatment, while the expression and phosphorylation level of mTOR were not altered. This indicates that the anti-ALL activity of MK-1775 was partly mediated by the downregulation of Notch pathway, rather than mTOR. However, additional study is required to identify how the Notch signaling pathway was regulated by Weel inhibitor MK-1775.

In conclusion, the results of the present study demonstrated that the Weel inhibitor, MK-1775, exhibited significant anti-ALL effects by inducing mitotic catastrophe and downregulation of the Notch pathway. The combination of MK-1775 and cytotoxic agents may be a promising anti-ALL regimen with high efficiency and good tolerance. Additional studies are warranted to examine the safety of this drug in vivo.

\section{Acknowledgements}

Not applicable.

\section{Funding}

The present study was supported by the National Nature Science Foundation of China (grant no. 81500130), Shandong Provincial Natural Science Foundation (grant no., ZR2015HQ026), Project of Shandong Province Higher Educational Science and Technology Programme (grant no., J14LL03) and Taian Science and Technology Programme (grant no., 2015NS2088).

\section{Availability of data and materials}

All datasets generated and analyzed in the present study are included in this published article.

\section{Authors' contributions}

YD and XD conducted experiments and wrote the manuscript. JN performed statistical analysis data, PL and FL analyzed data and participated in manuscript writing, and DM and CJ designed experiments.

\section{Ethics and consent to participate}

The research protocol was approved by the Human Ethics Committee of Qilu Hospital, Shandong University. Written informed consent was gained from all participants.

\section{Patient consent for publication}

All the participants provided consent for the data to be published.

\section{Competing interests}

The authors declare that they have no conflict of interest.

\section{References}

1. Yeoh AE, Tan D, Li CK, Hori H, Tse E and Pui CH; Asian Oncology Summit 2013: Management of adult and paediatric acute lymphoblastic leukaemia in Asia: Resource-stratified guidelines from the Asian Oncology Summit 2013. Lancet Oncol 14: e508-e523, 2013.

2. Alvarnas JC, Brown PA, Aoun P, Ballen KK, Bellam N, Blum W, Boyer MW, Carraway HE, Coccia PF, Coutre SE, et al: Acute lymphoblastic leukemia. J Natl Compr Canc Netw 10: 858-914, 2012.

3. Esparza SD and Sakamoto KM: Topics in pediatric leukemia-acute lymphoblastic leukemia. MedGenMed 7: 23, 2005.

4. Ma H, Sun H and Sun X: Survival improvement by decade of patients aged 0-14 years with acute lymphoblastic leukemia: A SEER analysis. Sci Rep 4: 4227, 2014.

5. Kenderian SS, Al-Kali A, Gangat N, Letendre L, Hogan WJ, Litzow MR and Patnaik MM: Monosomal karyotype in Philadelphia chromosome-negative acute lymphoblastic leukemia. Blood Cancer J 3: e122, 2013.

6. Koharazawa H, Kanamori H, Sakai R, Hashimoto C, Takemura S, Hattori M, Taguchi J, Fujimaki K, Tomita N, Fujita H, et al: Long-term outcome of L86 and L97 protocols for adult acute lymphoblastic leukemia. Leuk Lymphoma 49: 2133-2140, 2008

7. Pulte D, Jansen L, Gondos A, Katalinic A, Barnes B, Ressing M, Holleczek B, Eberle A and Brenner H: Survival of adults with acute lymphoblastic leukemia in Germany and the United States. PLoS One 9: e85554, 2014.

8. Inukai T: Mechanisms of drug resistance in acute lymphoblastic leukemia. Rinsho Ketsueki 57: 2022-2028, 2016 (In Japanese).

9. Nurse P: Wee beasties. Nature 432: 557, 2004.

10. Siripattarapravat K, Busta A, Steibel JP and Cibelli J: Characterization and in vitro control of MPF activity in zebrafish eggs. Zebrafish 6: 97-105, 2009.

11. Adhikari D and Liu K: The regulation of maturation promoting factor during prophase I arrest and meiotic entry in mammalian oocytes. Mol Cell Endocrinol 382: 480-487, 2014.

12. Hirai H, Iwasawa Y, Okada M, Arai T, Nishibata T, Kobayashi M, Kimura T, Kaneko N, Ohtani J, Yamanaka K, et al: Small-molecule inhibition of Wee1 kinase by MK-1775 selectively sensitizes p53-deficient tumor cells to DNA-damaging agents. Mol Cancer Ther 8: 2992-3000, 2009.

13. Creevey L, Ryan J, Harvey H, Bray IM, Meehan M, Khan AR and Stallings RL: MicroRNA-497 increases apoptosis in MYCN amplified neuroblastoma cells by targeting the key cell cycle regulator WEE1. Mol Cancer 12: 23, 2013.

14. Mackintosh C, García-Domínguez DJ, Ordóñez JL, Ginel-Picardo A, Smith PG, Sacristán MP and de Álava E: WEE1 accumulation and deregulation of S-phase proteins mediate MLN4924 potent inhibitory effect on Ewing sarcoma cells. Oncogene 32: 1441-1451, 2013.

15. Sarcar B, Kahali S, Prabhu AH, Shumway SD, Xu Y, Demuth T and Chinnaiyan P: Targeting radiation-induced G(2) checkpoint activation with the Wee-1 inhibitor MK-1775 in glioblastoma cell lines. Mol Cancer Ther 10: 2405-2414, 2011. 
16. Wang G, Niu X, Zhang W, Caldwell JT, Edwards H, Chen W, Taub JW, Zhao L and Ge Y: Synergistic antitumor interactions between MK-1775 and panobinostat in preclinical models of pancreatic cancer. Cancer Lett 356: 656-668, 2015.

17. Carrassa L, Chilà R, Lupi M, Ricci F, Celenza C, Mazzoletti M, Broggini $\mathrm{M}$ and Damia G: Combined inhibition of Chk1 and Wee1: In vitro synergistic effect translates to tumor growth inhibition in vivo. Cell Cycle 11: 2507-2517, 2012.

18. Ghiasi N, Habibagahi M, Rosli R, Ghaderi A, Yusoff K, Hosseini A, Abdullah S and Jaberipour M: Tumour suppressive effects of WEE1 gene silencing in breast cancer cells. Asian Pac J Cancer Prev 14: 6605-6611, 2014.

19. Kogiso T, Nagahara H, Hashimoto E, Ariizumi S, Yamamoto $M$ and Shiratori K: Efficient induction of apoptosis by weel kinase inhibition in hepatocellular carcinoma cells. PLoS One 9: e100495, 2014.

20. Porter CC, Kim J, Fosmire S, Gearheart CM, van Linden A, Baturin D, Zaberezhnyy V, Patel PR, Gao D, Tan AC, et al: Integrated genomic analyses identify WEE1 as a critical mediator of cell fate and a novel therapeutic target in acute myeloid leukemia. Leukemia 26: 1266-1276, 2012.

21. Qi W, Xie C, Li C, Caldwell JT, Edwards H, Taub JW, Wang Y, Lin $\mathrm{H}$ and Ge Y: CHK1 plays a critical role in the anti-leukemic activity of the weel inhibitor MK-1775 in acute myeloid leukemia cells. J Hematol Oncol 7: 53, 2014

22. Tizzani A, Casetta G, Gontero P, Giammò A, Ghabin H, Demurtas S and Pacchioni D: DNA flow cytometry and $67 \mathrm{~K}$ proliferating index as prognostic factors of early recurrence and progression in G1-G2/Ta-T1 and G3/Ta-T1 transitional cel carcinoma of the bladder. Minerva Urol Nefrol 49: 141-143, 1997.

23. Wei Y, Mizzen CA, Cook RG, Gorovsky MA and Allis CD Phosphorylation of histone $\mathrm{H} 3$ at serine 10 is correlated with chromosome condensation during mitosis and meiosis in Tetrahymena. Proc Natl Acad Sci USA 95: 7480-7484, 1998.

24. Mateo J, Boysen G, Barbieri CE, Bryant HE, Castro E, Nelson PS, Olmos D, Pritchard CC, Rubin MA and de Bono JS DNA repair in prostate cancer: Biology and clinical implications. Eur Urol 71: 417-425, 2017.

25. Shang X, Shiono Y, Fujita Y, Oka S and Yamazaki Y: Synergistic enhancement of apoptosis by DNA- and cytoskeleton-damaging agents: A basis for combination chemotherapy of cancer. Anticancer Res 21: 2585-2589, 2001.

26. Carr AM, Green MH and Lehmann AR: Checkpoint policing by p53. Nature 359: 486-487, 1992

27. Xie G, Habbersett RC, Jia Y, Peterson SR, Lehnert BE, Bradbury EM and D'Anna JA: Requirements for p53 and the ATM gene product in the regulation of G1/S and S phase checkpoints. Oncogene 16: 721-736, 1998.

28. Hamzehloie T, Mojarrad M, Hasanzadeh Nazarabadi M and Shekouhi S: The role of tumor protein 53 mutations in common human cancers and targeting the murine double minute 2-p53 interaction for cancer therapy. Iran J Med Sci 37: 3-8, 2012.

29. McGowan $\mathrm{CH}$ and Russell P: Cell cycle regulation of human WEE1. EMBO J 14: 2166-2175, 1995.

30. Garcia K, Stumpff J, Duncan T and Su TT: Tyrosines in the kinesin-5 head domain are necessary for phosphorylation by Wee1 and for mitotic spindle integrity. Curr Biol 19: 1670-1676, 2009.

31. Cornago M, Garcia-Alberich C, Blasco-Angulo N, Vall-Llaura N, Nager M, Herreros J, Comella JX, Sanchis D and Llovera M: Histone deacetylase inhibitors promote glioma cell death by G2 checkpoint abrogation leading to mitotic catastrophe. Cell Death Dis 5: e1435, 2014

32. De Witt Hamer PC, Mir SE, Noske D, Van Noorden CJ and Würdinger T: WEE1 kinase targeting combined with DNA-damaging cancer therapy catalyzes mitotic catastrophe. Clin Cancer Res 17: 4200-4207, 2011.

33. Aarts M, Sharpe R, Garcia-Murillas I, Gevensleben H, Hurd MS, Shumway SD, Toniatti C, Ashworth A and Turner NC: Forced mitotic entry of S-phase cells as a therapeutic strategy induced by inhibition of WEE1. Cancer Discov 2: 524-539, 2012.
34. Heale JT, Ball AR Jr, Schmiesing JA, Kim JS, Kong X, Zhou S, Hudson DF, Earnshaw WC and Yokomori K: Condensin I interacts with the PARP-1-XRCC1 complex and functions in DNA single-strand break repair. Mol Cell 21: 837-848, 2006.

35. Bharti AC, Takada Y and Aggarwal BB: PARP cleavage and caspase activity to assess chemosensitivity. Methods Mol Med 111: 69-78, 2005.

36. Cruet-Hennequart S, Prendergast ÁM, Shaw G, Barry FP and Carty MP: Doxorubicin induces the DNA damage response in cultured human mesenchymal stem cells. Int J Hematol 96: 649-656, 2012

37. Kreahling JM, Foroutan P, Reed D, Martinez G, Razabdouski T, Bui MM, Raghavan M, Letson D, Gillies RJ and Altiok S: Weel inhibition by MK-1775 leads to tumor inhibition and enhances efficacy of gemcitabine in human sarcomas. PLoS One 8: e57523, 2013.

38. Kreahling JM, Gemmer JY, Reed D, Letson D, Bui M and Altiok S: MK1775, a selective Wee1 inhibitor, shows single-agent antitumor activity against sarcoma cells. Mol Cancer Ther 11: 174-182, 2012.

39. Mir SE, De Witt Hamer PC, Krawczyk PM, Balaj L, Claes A, Niers JM, Van Tilborg AA, Zwinderman AH, Geerts D, Kaspers GJ, et al: In silico analysis of kinase expression identifies WEE1 as a gatekeeper against mitotic catastrophe in glioblastoma. Cancer Cell 18: 244-257, 2010

40. PosthumaDeBoer J, Würdinger T, Graat HC, van Beusechem VW, Helder MN, van Royen BJ and Kaspers GJ: WEE1 inhibition sensitizes osteosarcoma to radiotherapy. BMC Cancer 11: 156, 2011.

41. Nwabo Kamdje AH and Krampera M: Notch signaling in acute lymphoblastic leukemia: Any role for stromal microenvironment? Blood 118: 6506-6514, 2011.

42. Penton AL, Leonard LD and Spinner NB: Notch signaling in human development and disease. Semin Cell Dev Biol 23: 450-457, 2012

43. Weng AP, Ferrando AA, Lee W, Morris JP IV, Silverman LB, Sanchez-Irizarry C, Blacklow SC, Look AT and Aster JC: Activating mutations of NOTCH1 in human T cell acute lymphoblastic leukemia. Science 306: 269-271, 2004

44. Yin C, Ye J, Zou J, Lu T, Du Y, Liu Z, Fan R, Lu F, Li P, $\mathrm{Ma} \mathrm{D}$, et al: Role of stromal cells-mediated Notch-1 in the invasion of T-ALL cells. Exp Cell Res 332: 39-46, 2015.

45. Herranz D, Ambesi-Impiombato A, Palomero T, Schnell SA, Belver L, Wendorff AA, Xu L, Castillo-Martin M, Llobet-Navás D, Cordon-Cardo C, et al: A NOTCH1-driven MYC enhancer promotes T cell development, transformation and acute lymphoblastic leukemia. Nat Med 20: 1130-1137, 2014.

46. Zou J, Li P, Lu F, Liu N, Dai J, Ye J, Qu X, Sun X, Ma D, Park J, et al: Notch1 is required for hypoxia-induced proliferation, invasion and chemoresistance of T-cell acute lymphoblastic leukemia cells. J Hematol Oncol 6: 3, 2013.

47. Nwabo Kamdje AH, Mosna F, Bifari F, Lisi V, Bassi G, Malpeli G, Ricciardi M, Perbellini O, Scupoli MT, Pizzolo G, et al: Notch-3 and Notch-4 signaling rescue from apoptosis human B-ALL cells in contact with human bone marrow-derived mesenchymal stromal cells. Blood 118: 380-389, 2011.

48. Itoh M, Fu L and Tohda S: NF-kappaB activation induced by Notch ligand stimulation in acute myeloid leukemia cells. Oncol Rep 22: 631-634, 2009.

49. Baldoni S, Sportoletti P, Del Papa B, Aureli P, Dorillo E, Rosati E, Ciurnelli R, Marconi P, Falzetti F and Di Ianni M: NOTCH and NF- $\kappa B$ interplay in chronic lymphocytic leukemia is independent of genetic lesion. Int J Hematol 98: 153-157, 2013.

50. Chan SM, Weng AP, Tibshirani R, Aster JC and Utz PJ: Notch signals positively regulate activity of the mTOR pathway in T-cell acute lymphoblastic leukemia. Blood 110: 278-286, 2007.

51. Wang Z, Li Y, Banerjee S, Kong D, Ahmad A, Nogueira V, Hay N and Sarkar FH: Down-regulation of Notch-1 and Jagged-1 inhibits prostate cancer cell growth, migration and invasion and induces apoptosis via inactivation of Akt, mTOR and NF-kappaB signaling pathways. J Cell Biochem 109: 726-736, 2010. 